\title{
SERUM ELECTROLYTES IN LEPTOSPIROSIS
}

\author{
Galya Gancheva, Maria Atanasova, Penka Ilieva \\ Department of Infectious Diseases, Epidemiology, Parasitology and Tropical \\ Medicine \\ Medical University, Pleven, Bulgaria
}

\section{SUMMARY:}

Serum levels of electrolytes (sodium, chlore, potassium and ionized calcium) in ninety four cases of leptospirosis have been investigated dynamically with routine laboratory methods. Twenty six cases had been with mild course $(27,66 \%)$, thirty eight with moderate $(40,43 \%)$, and thirty with severe leptospirosis $(31,91 \%)(p>0,1)$. The comparison of different serum levels (decreased, normal and increased) of the electrolytes and their averages have revealed significantly increasing only of sodium average before discharge $(p<0,05)$. Analysis of the percentage of cases with different serum levels (normal, below and above normal) of electrolytes in different severity of the disease has been found significantly higher occurrence of hyponatriemia in moderate and severe leptospirosis $(p<0,05)$. Decreased serum levels of ionized calcium have been established in thirteen cases, twelve of them with severe leptospirosis $(p<0,05)$. The dynamical control on the serum levels of sodium, chlore, and potassium have not revealed significant differences in percentage of the disorders $(p>0,05)$. Marked prevalence of the cases with decreased ionized calcium during the hospital period has been observed $(p<0,02)$. In conclusion: electrolytic disorders have not been significant for diagnosis of leptospirosis because they have been observed in ARF independent of the etiology but they have been important for evaluation of the severity and correct treatment of the disease.

Key words: leptospirosis, acute renal failure, serum electrolytes, sodium, chlore, potassium, ionized calcium.

Leptospirosis is zoonosis with worldwide distribution. The course of the disease is acute with multiorgan disorders. Pathological damages of the kidneys, liver and cardiovascular system are most significant. The symptoms of the lungs and nervous system are uncommon but important for severity. The pancreas is rarely clinically involved but asymptomatic amylasemia is frequently observed $(3,8)$. The clinical syndromes of leptospirosis are with broad spectrum and occur in variable combinations in different cases (12). Laboratory parameters are with numerous abnormalities. Serum electrolytes are with significant disorders which have been provoked from different reasons (13). With a greatest importance is the acute renal failure (ARF) $(11,14)$, frequently occurred in leptospirosis $(2,3,4,5,6,7,8,9,10,14)$. At the same time pathological changes in serum levels of the electrolytes cause functional disorders in cardiovascular system and pancreas $(1,3)$ and contribute a dysbalance in electrolytic and acid-base homeostasis $(4,7,9,14)$. Electrolytic disorders are important for severity and outcome of leptospirosis $(4,8,9)$.

The aim of this research is analysis of the electrolytic parameters in cases of leptospirosis with different severity and their dynamic in the course of the disease.

\section{MATERIALS AND METHODS:}

The research has been involved ninety four cases of leptospirosis which have been treated in Clinic of Infectious Diseases - Pleven for thirty years (1976 to 2005). Serum levels of electrolytes (sodium, chlore, potassium and ionized calcium) have been investigated with routine laboratory methods. The parameters have been controlled dynamically - in the hospital admission, in the course of the disease, and before discharge.

\section{RESULTS:}

Twenty six cases $(27,66 \%)$ had been with mild course, thirty eight with moderate $(40,43 \%)$, and thirty with severe leptospirosis $(31,91 \%)(p>0,1)$.

On the Table 1 the frequency of different serum levels (decreased, normal and increased) of the electrolytes and their averages have been presented. The parameters have been investigated at admission (1), in the course of disease (2) and before discharge (3). Only the sodium average has been significantly increased before discharge $(p<0,05)$.

On the Table 2 percentage of cases with different serum levels (normal, below and above normal) of electrolytes in different severity of the disease have been presented. Significantly higher occurrence of hyponatriemia in moderate and severe leptospirosis has been observed $(p<0,05)$. Decreased serum levels of ionized calcium have been established in thirteen cases, twelve of them with severe leptospirosis $(p<0,05)$. Serum levels of chlore and potassium have not revealed significant disorders $(p>0,05)$.

The dynamic control on the serum levels of sodium 
(Figure 1), chlore (Figure 2), and potassium (Figure 3) have not revealed significant differences in percentage of the disorders $(p>0,05)$. Marked prevalence of the cases with decreased ionized calcium (Figure 4) during the hospital period has been observed $(p<0,02)$.

\section{DISCUSSION:}

More authorities (Covic et al., Yang et al., YounesIbrahim et al.) have considerate that pathological alterations in the kidneys have been provoked by hypoxemia and toxic injury. Experimentally has been confirmed that increasing of the sodium concentration in distal tubules leads to decreasing of glomerular filtration. The low sodium concentration has been supported by oxygen dependent reabsorption of the sodium and chlore in the tick ascending of the loop of Henle. Hypoxia and toxinaemia suppress the oxidative burst in tubular cells. Decreased synthesis of ATP in these cells leads to increasing of sodium and chlore levels with consequent cellular edema. The decreased sodium reabsorption stimulates osmotic receptors in macula dense with turn on of rennin-angiotensine system and a spasm of the glomerulus's arterioles. The injury of the intracellular structures in the tubular cells decreases ability for protein reabsorption. Depression of the oxidative burst leads to increasing of the intracellular calcium which contributes acute tubular necrosis. Simultaneously with regeneration of the tubular cells a normalization of the sodium reabsorption has been observed and its concentration in macula dense decreases. This is followed in poliuric phase $(7,12,13)$. These tendencies have not been fully correlated with our observation - sodium levels have been decreased at admission in $33,78 \%$, during the course of leptospirosis in $41,07 \%$, at discharge in $20,93 \%$ of cases. Sodium average has been significantly often increased at discharge than at admission $(p<0,05)$. Chlorine levels at admission, during the course and at discharge have been decreased respectively in $31,82 \%$, in $40,63 \%$ and $23,81 \%$ of cases ( $>00,1)$. The report of Younes-Ibrahim et al. (1997) suggests that the omnipresent $\mathrm{Na}^{+}-\mathrm{K}^{+}$ATPase along nephron is a molecular target for Leptospira interrogans endotoxin, and the glycolipoprotein fraction extracted from Leptospira interrogans contains a potent inhibitor of renal $\mathrm{Na}^{+}-\mathrm{K}^{+}$ ATPase. The inhibition of $\mathrm{Na}^{+}-\mathrm{K}^{+}$ATPase subsequently affects the apical located $\mathrm{Na}^{+}-\mathrm{K}^{+}-\mathrm{CL}^{+}$cotransporter and accounts for the observed potassium vasting according to Younes-Ibrahim et al. (1997) (13). We have not found data in the literature about ionized calcium in leptospirosis. Hypocalcaemia is related with pancreatic injury which has been observed from Atanasova et al. $(2005)(1,3)$.

\section{CONCLUSION:}

Electrolytic disorders are not significant for diagnosis of leptospirosis because have been observed in ARF independent of the etiology. At the same time they are important for evaluation of the severity and correct treatment of the disease.

Table 1. Averages and frequency of different serum levels (decreased $-<\mathrm{N}$, normal $-\mathrm{N}$, increased $->\mathrm{N}$ ) of the electrolytes, investigated at admission ${ }_{1}$, in the course 2 and before discharge 3

\begin{tabular}{|l|c|c|c|c|c|c|c|}
\hline electrolytes & $\mathbf{n}$ & $<\mathbf{N}$ & $\mathbf{N}$ & $>\mathbf{N}$ & $\mathbf{a v}$ & $\mathbf{S D}$ & $\mathbf{p}$ \\
\hline $\mathbf{N a}_{\mathbf{1}}$ & 74 & $33,78 \%$ & $64,86 \%$ & $1,35 \%$ & $\mathbf{1 3 7 , 9 9}$ & 6,74 & $1: 2>0,1$ \\
\hline $\mathbf{N a}_{\mathbf{2}}$ & 56 & $41,07 \%$ & $58,93 \%$ & - & $\mathbf{1 3 8 , 3 0}$ & 7,83 & $2: 3>0,1$ \\
\hline $\mathbf{N a}{ }_{\mathbf{3}}$ & 43 & $20,93 \%$ & $76,74 \%$ & $2,33 \%$ & $\mathbf{1 4 0 , 6 7}$ & 6,99 & $\mathbf{3 : 1}<\mathbf{0 , 0 5}$ \\
\hline $\mathbf{C l}_{\mathbf{1}}$ & 44 & $31,82 \%$ & $65,91 \%$ & $2,27 \%$ & $\mathbf{9 8 , 2 0}$ & 8,31 & $1: 2>0,1$ \\
\hline $\mathbf{C l}_{\mathbf{2}}$ & 32 & $40,63 \%$ & $56,25 \%$ & $3,13 \%$ & $\mathbf{9 7 , 5 9}$ & 9,55 & $2: 3>0,1$ \\
\hline $\mathbf{C l}_{\mathbf{3}}$ & 21 & $23,81 \%$ & $71,43 \%$ & $4,76 \%$ & $\mathbf{1 0 0 , 4 3}$ & 6,53 & $3: 1>0,1$ \\
\hline $\mathbf{K}_{\mathbf{1}}$ & 74 & $20,27 \%$ & $77,03 \%$ & $2,70 \%$ & $\mathbf{4 , 1 0}$ & 0,75 & $1: 2>0,1$ \\
\hline $\mathbf{K}_{\mathbf{2}}$ & 56 & $28,57 \%$ & $66,07 \%$ & $5,36 \%$ & $\mathbf{4 , 0 1}$ & 0,84 & $2: 3>0,1$ \\
\hline $\mathbf{K}_{\mathbf{3}}$ & 43 & $25,58 \%$ & $69,77 \%$ & $4,65 \%$ & $\mathbf{4 , 1 5}$ & 0,86 & $3: 1>0,1$ \\
\hline $\mathbf{C a}^{2+} \mathbf{1}$ & 19 & $68,42 \%$ & $26,32 \%$ & $5,26 \%$ & $\mathbf{1 , 0 6}$ & 0,14 & $1: 2<0,1$ \\
\hline $\mathbf{C a}^{\mathbf{2 +}}{ }_{\mathbf{2}}$ & 12 & $83,33 \%$ & $8,33 \%$ & $8,33 \%$ & $\mathbf{1 , 0 5}$ & 0,17 & $2: 3<0,1$ \\
\hline $\mathbf{C a}^{2+}{ }_{\mathbf{3}}$ & 8 & $67,50 \%$ & $12,50 \%$ & - & $\mathbf{1 , 0 7}$ & 0,09 & $3: 1<0,1$ \\
\hline
\end{tabular}


Table 2. Serum electrolytes in leptospirosis - percentage of levels (normal $-\mathrm{N}$, below $-<\mathrm{N}$ and above normal $->\mathrm{N}$ ) in different severity of the disease

\begin{tabular}{|c|c|c|c|c|c|c|c|c|c|c|c|c|c|c|}
\hline \multirow{2}{*}{\multicolumn{2}{|c|}{ electrolytes $\%$}} & \multicolumn{3}{|c|}{ mild } & \multicolumn{3}{|c|}{ moderate } & \multicolumn{3}{|c|}{ severe } & \multicolumn{3}{|c|}{ total } & \multirow[b]{2}{*}{$\mathrm{p}$} \\
\hline & & av. & sd & $\%$ & av. & $\mathrm{sd}$ & $\%$ & av. & $\mathrm{sd}$ & $\%$ & av. & sd & & \\
\hline \multirow{3}{*}{$\mathrm{Na}$} & $<\mathbf{N}$ & 5,88 & \multirow{3}{*}{143} & \multirow{3}{*}{4,13} & 48,15 & \multirow{3}{*}{137} & \multirow{3}{*}{7,25} & 36,67 & \multirow{3}{*}{136} & \multirow{3}{*}{6,32} & 33,78 & \multirow{3}{*}{138} & \multirow{3}{*}{6,74} & $<0,05$ \\
\hline & $\mathbf{N}$ & 94,12 & & & 48,15 & & & 63,33 & & & 64,86 & & & $>0,05$ \\
\hline & $>\mathbf{N}$ & - & & & 3,70 & & & - & & & 1,35 & & & $>0,05$ \\
\hline \multirow{3}{*}{$\mathrm{Cl}$} & $<\mathbf{N}$ & - & \multirow{3}{*}{102} & \multirow{3}{*}{2,55} & 38,10 & \multirow{3}{*}{96,1} & \multirow{3}{*}{7,52} & 42,86 & \multirow{3}{*}{99,1} & \multirow{3}{*}{11,0} & 31,82 & \multirow{3}{*}{98,2} & \multirow{3}{*}{8,31} & $>0,05$ \\
\hline & $\mathbf{N}$ & 100 & & & 61,90 & & & 50,00 & & & 65,91 & & & $>0,05$ \\
\hline & $>\mathbf{N}$ & & & & - & & & 7,14 & & & 2,27 & & & $>0,05$ \\
\hline \multirow{3}{*}{ K } & $<\mathbf{N}$ & 11,76 & \multirow{3}{*}{4,28} & \multirow{3}{*}{0,63} & 33,33 & \multirow{3}{*}{3,88} & \multirow{3}{*}{0,77} & 13,33 & \multirow{3}{*}{4,20} & \multirow{3}{*}{0,76} & 20,27 & \multirow{3}{*}{4,10} & \multirow{3}{*}{0,75} & $>0,05$ \\
\hline & $\mathbf{N}$ & 88,24 & & & 62,96 & & & 83,33 & & & 77,03 & & & $>0,05$ \\
\hline & $>\mathbf{N}$ & - & & & 3,71 & & & 3,33 & & & 2,70 & & & $>0,05$ \\
\hline \multirow{3}{*}{$\mathrm{Ca}^{2+}$} & $<\mathbf{N}$ & - & \multirow{3}{*}{0,95} & & 33,33 & & & 85,71 & & & 68,42 & & & $<0,02$ \\
\hline & $\mathbf{N}$ & 100 & & 0,14 & 66,67 & 1,02 & 0,10 & 7,14 & 1,36 & 0,47 & 26,32 & 1,06 & 0,14 & $>0,05$ \\
\hline & $>\mathbf{N}$ & - & & & - & & & 7,14 & & & 5,26 & & & $>0,05$ \\
\hline
\end{tabular}

Figure 1. Dynamic of the sodium - percentage of different serum levels

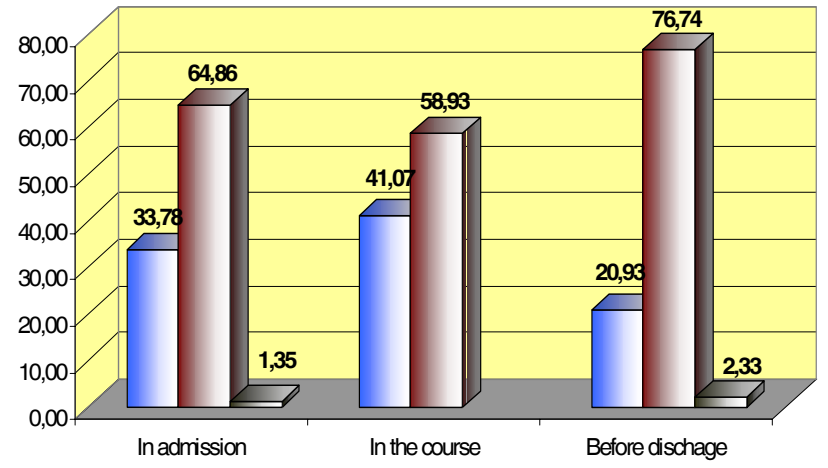

$\square \triangleleft N \square N \square>N$
Figure 2. Dynamic of the chlore - percentage of different serum levels

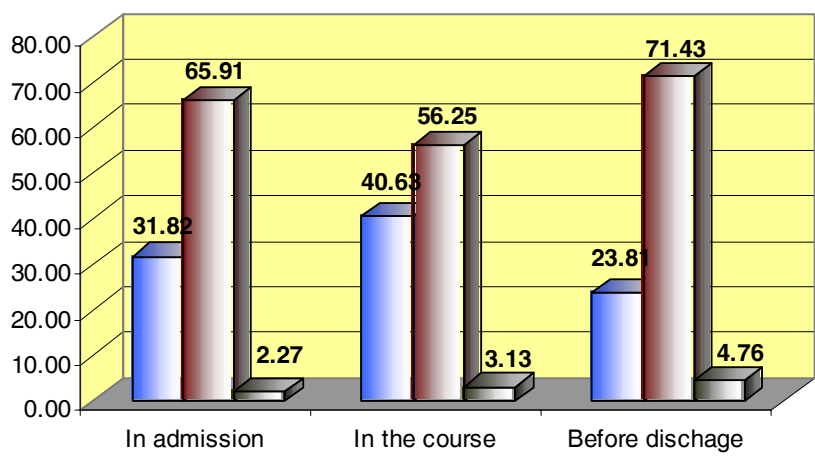

$\square<\mathbf{N} \square \mathbf{N} \square>\mathbf{N}$ 
Figure 3. Dynamic of the potassium - percentage of different serum levels

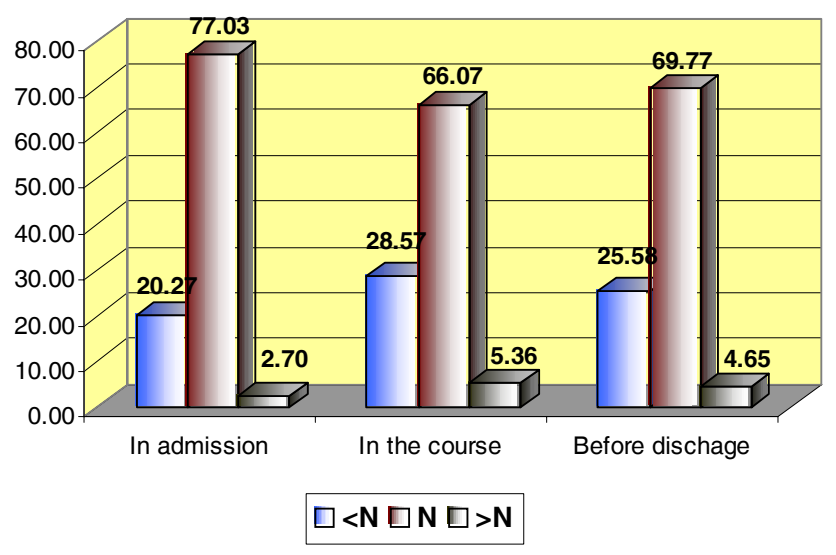

Figure 4. Dynamic of the ionized calcium - percentage of different serum levels

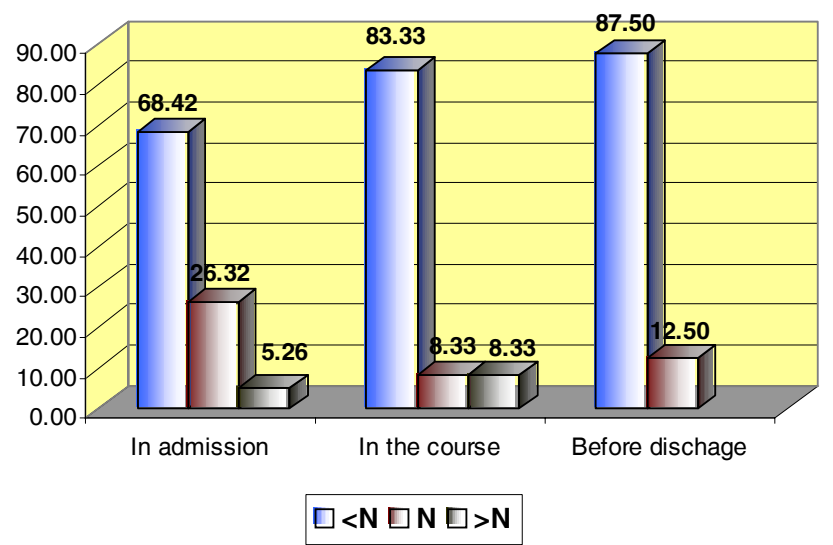

\section{REFERENCES:}

1. Atanasova M. Acute pancreatitis. Published Center "MU - Pleven, 2005, 88. Bulgarian.

2. Abdulkader R. C., Seguro A. C., Malheiro P. S., Burdmann EA, Marcondes M. Peculiar electrolytic and hormonal abnormalities in acute renal failure due to leptospirosis. Am J Trop Med Hyg. 1996 Jan; 54(1): 1-6.

3. Atanasova M., G. Gancheva, P. Ilieva, Chr. Tzvetanova, I. Simova. Pancreatic Involvement in Leptospirosis. Online Journal of IMAB, Issue 2005, book 1, part medicine. www.journal-imab-bg.org/ en/vol-11 book-1.htm

4. Berezovskaia Z. B., Mishshuk I. I., Ossovskaia A. B., Kochetova M. V., Poberezhets S. Iu., Advashkova I. A. The characteristics of the course and treatment of severe forms of leptospirosis. Lik Sprava. 1994 Feb;(2):84-5.

5. Cengiz K., Sahan C., Sunbul M., Leblebicioglu H., Cuner F. Acute renal failure in leptospirosis in the black-sea region in Turkey. Int Urol Nephrol. 2002;
33(1): 133-6.

6. Cetin B. D., Harmankaya O., Hasman H., Gunduz A., Oktar M., Seber E. Acute renal failure: a common manifestation of leptospirosis. Ren Fail. 2004 Nov; 26(6): 655-61.

7. Covic A., Goldsmith D.J., GusbethTatomir P., Seica A., Covic M. A retrospective 5-year study in Moldova of acute renal failure due to leptospirosis: 58 cases and review of the literature. Nephrol Dial Transplant. 2003 Jun; 18(6): 1128-34.

8. Gancheva G. Complex studies in leptospirosis. Dissertation, 2007, 19, 137144. Bulgarian.

9. Gancheva G., P. Ilieva, M. Atanasova, Chr. Tzvetanova, I. Simova. Tanatogenesis in Leptospirosis. Online Journal of IMAB, Issue 2005, book 1, part medicine. www.journal-imab-bg.org/en/vol11 book-1.htm

10. Gancheva G., P. Ilieva, M. Atanasova, Chr. Tzvetanova, I. Simova. Hemodiaperfusion in Leptospirosis. Online J of IMAB, Issue 2005, book 1, part medicine. www.journal-imab-bg.org/en/vol11 book-1.htm

11. Golubic D, Markotic A. Leptospirosis and hemorrhagic fever with renal syndrome in northwestern Croatia. Acta Med Croatica. 2003;57(5):369-72.

12. Yang H.Y., Hsu P.Y., Pan M.J., Wu M.S., Lee C.H., Yu C.C., Hung C.G., Yang $\mathrm{CW}$. Clinical distinction and evaluation of leptospirosis in Taiwan - a case control study. J Nephrol. 2005 Jan-Feb; 18(1): 4553.

13. Younes-Ibrahim M., Buffin-Meyer B., Cheval L. et al. Na, K-ATPase: a molecular target for Leptospira interrogans endotoxin. Braz J Med Biol Res. 1997; 30: 213-223.

14. Zhukova L.I., Mel'nik G.V.. Clinical and pathogenic evaluation of acidbase, gas and electrolyte homeostasis in patients with leptospirosis and acute renal insufficiency. Lik Sprava. 2002; (2): 43-6. Russian.

Address for correspondence:

Galya Ivanova Gancheva

Department of Infectious Diseases, University Hospital - Pleven,

8A, Georgy Cochev str., 5800 Pleven, Bulgaria

Tel.: +359/64/886 301; Fax: +359/64/886 439

E-mail: galya_gancheva@abv.bg 